\title{
Tracing Transit (in)Tensions Between Settler Colonized ECE Contact Zones
}

\author{
Sherri-Lynn Yazbeck, Miriam Brown, Ildikó Danis, and Narda Nelson
}

\begin{abstract}
Sherri-Lynn Yazbeck is an early childhood educator at University of Victoria (UVic) Child Care Services and a MEd student at UVic. Drawing on her background in psychology, philosophy, and early childhood education and inspired by everyday moments with children, she is interested in the entangled multispecies relationships and encounters that take place in the classroom, playground, nearby forests, and gardens. She is intrigued by how these human and more-than-human assemblages create place and pedagogy in early education. She is also researching what it might mean to practice care and sustainability through these children-more-thanhuman relationships. Email: syazbeck@uvic.ca
\end{abstract}

Miriam Brown is an early childhood teacher at Clare Court Children's Service in Melbourne, Australia, where she is a practice partner in Out and About, a place-based research project with the multidisciplinary Common Worlds Research Collective. Drawing on common worlds frameworks and Indigenous relational theory, she is interested in how postdevelopmental approaches generate activism and new ways of thinking with place, challenging traditional notions of environmental stewardship. Miriam completed her MTeach at the University of Melbourne in 2017. Email: info@clarecourt.com.au

Ildikó Danis is an early childhood educator at UVic Child Care Services and a MEd student at UVic. She has a degree in early childhood special needs education from Georgia State University, Atlanta, and experience in Canadian, US, and Hungarian educational environments. Her interest in the complex and inclusive ways of forming "natural childhoods" spurred her curiosity about children's relations with place and everyday, natural materials. Her focus on child-material relations and movement pedagogies is motivated by a commitment to attending to stories and events that evolve by chance in the themes of children's relations with other species, with the material world, and with place. Email: idanis12@uvic.ca

Narda Nelson is a pedagogist and researcher with UVic Child Care Services and a member of the Common Worlds Research Collective and the Early Childhood Pedagogies Collaboratory. Drawing on her master's in the UVic School of Child and Youth Care and background in gender studies, Narda takes an interdisciplinary approach to early childhood research with a particular focus on reimagining ethical futures with animals, plants, and waste flows in early childhoods. Email: nelsonn@uvic.ca

Tracing the curiosity of children, educators, and researchers at a childcare centre in Melbourne, Australia and Victoria, British Columbia, Canada, we wonder how we might connect digitally across continents while thinking with place-specific encounters and tensions. In this article we share stories and unexpected (in)tensions that arise during a FaceTiming inquiry to invite questions that unsettle sedimented notions of who and what belongs in the colonized places in which our settler educator practices take place. Provoked by Donna Haraway's SF string figure method and situating our work within a common worlds framework, we seek new ways of connecting and transiting between our respective contact zones. In this article, we follow and pull at unsettling threads with the giving and receiving of two puppets, Bunjil and Waa, as they travel from their home in the Australian settler contact zone to the hands of those in the Canadian settler contact zone. These practices trace how these woven threads presence transit (in)tensions continue to stretch our thinking and modes of participating in our attempts at becoming accountable within the common worlds and our stories. How might this messy work make visible our accountabilities and inheritances in places of ongoing settler colonialism?

Key words: early childhood; FaceTime; colonization; common worlds; place; contact zones

We acknowledge and pay our respects to the Lkwungen-speaking peoples, specifically the Songhees, Esquimalt, and WSÁNEĆ peoples, whose historical relationships with the lands where we live and learn continue to this day in Victoria, Canada, and to the Woi Wurrung-speaking Marin Balluk people of unceded Wurundjeri country in Melbourne, Australia, where our work unfolds. Our work is not made complete by acknowledging territory, especially as we continue to inhabit and think with stolen land. We hope that as we continue to think together, 
we might collectively work toward becoming accountable to the complexities, demands, and active ethical and political answerabilities of living in settler colonial spaces.

We sit next to creek, waiting for an iPhone ring to spark countless digital cellular data threads that connect us with a woods-park-child-educator assemblage a continent away. These clear but muddled, familiar but different, close but far away encounters leave us wondering: How do we, as settlers, give and receive consequential stories with place with children? (Clare Court field notes, March 2017)

Two years ago, our FaceTiming Common Worlds inquiry began with curiosity. How might we connect digitally with children across continents while thinking with place-specific encounters and tensions? What might be required of us, as early childhood educators, to generate new possibilities for thinking collectively with local and global ethics and politics in settler colonial lifeworlds? We began this project with the hope of sharing stories that make public, and force us to grapple with, the tensions of living and working on Indigenous territories. The stories we tell in this article are the product of our curiosity.

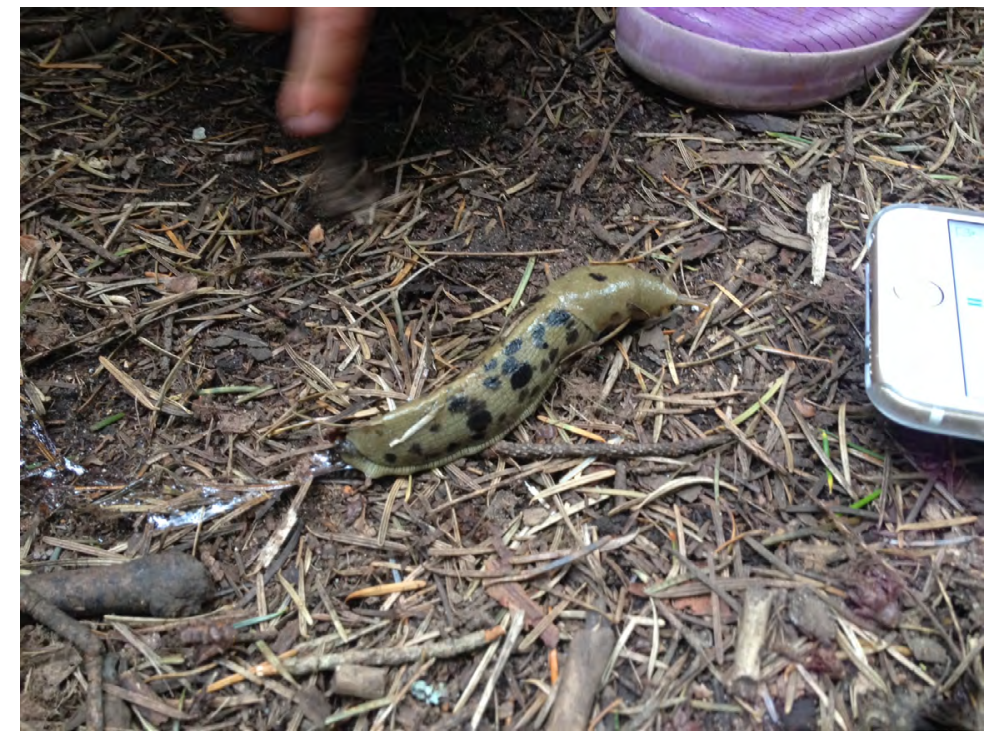

Figure 1. Connecting digitally with place-specific encounters.

We begin the article by introducing the Canadian and Australian settler colonial contact zones within which our early childhood education inquiry took place. Next, we situate our work within a common worlds conceptual framework and pedagogical approach (Taylor, 2017; Taylor \& Giugni, 2012; Land et al., 2019; Nxumalo \& Pacini-Ketchabaw, 2017) and explain how we have been provoked by Donna Haraway's (2016) SF string figure methods to find new ways of connecting, relaying, and transiting between our respective contact zones. We then tell the story of how our digitally transiting FaceTiming inquiry developed new, unsettling connecting threads and dimensions when it incorporated the material transiting presence of two puppets, Bunjil and Waa, as they travelled from their home in the Australian settler colonial contact zone to visit children in the Canadian contact zone. We conclude by tracing how these tightly woven threads to presence "transit (in)tensions" continue to emerge and stretch our thinking as we attempt to become accountable to the stories and settler colonial places within which we reside.

The purpose of this article is to invite questions that unsettle sedimented notions of who and what belongs in the colonized places in which our settler educator practices take place. That is to say that, in both Canadian and Australian early learning contexts, we are settlers working on colonized lands with long histories of injustice to Indigenous peoples. As educators and researchers working in the very institution used to inflict many of these colonial injustices (Truth and Reconciliation Commission of Canada, 2015), we feel a moral imperative to continue working, to the best of our ability, toward becoming accountable to those on whose lands we teach young children. The questions highlighted here represent just a few of many ongoing, emergent questions we do not know how to answer. In both Canadian and Australian early childhood educational fields, there continues to be an expectation for educators to take up a "best practices" approach through their training. Whereas so-called best practices often 
require early childhood educators to come up with answers, we believe that the questions we continue to ask in this piece provide an alternative and necessarily unsettling approach. We do not know exactly what is required to care with the stories, presences, histories, and connections we share across oceans (Haro Woods et al., 2018; Iorio, Hamm, Parnell, \& Quintero, 2017), but we continue to ask: How do we think together while we grapple with different settler colonial politics?

\section{Settler colonized contact zones}

Haraway (2008) uses the term contact zones to describe the generative tensions and mutually transformative effects of multispecies encounters and interactions. She borrows the concept from Mary Louise Pratt (1991, 1992), who originally used it to describe the process of imperial transculturation, or the unpredictable ways that colonizers and colonized people change each other in colonized places. In our settler colonized settings, we have come to know these contact zones through our messy, knotted-together entanglements with frogs, banana slugs, trees, water, woods, park, and FaceTime. Like those Haraway (2008) describes, these situated contact zones "are full of the complexities of different kinds of unequal power that do not always go in expected directions" (p. 218). Thinking with contact zones requires us to attune, respond, and become-with while recognizing, as Haraway (2008) writes, that "contact zones are where the action is, and current interactions change interactions to follow ... Contact zones change the subject-all the subjects-in surprising ways" (p. 219).

Arbutus Place is a centre for children 3-5 years of age at the University of Victoria Child Care Services in Victoria, British Columbia, Canada. As stated above, our Arbutus Place work takes place on Songhees, Esquimalt, and WSÁNEĆ unceded territory. Koala Group, a kindergarten program, is part of Clare Court Children's Service in Yarraville, an inner-urban suburb of Melbourne, Australia. The communityrun service is an integrated early childhood education hub built on the unceded land of the Marin Balluk people, Wurundjeri country. Most of the educators, researchers, and children of Arbutus Place and Koala Group are settlers to these places. As such, we work with an ethic of grappling with settler accountabilities in places of ongoing settler colonialism.

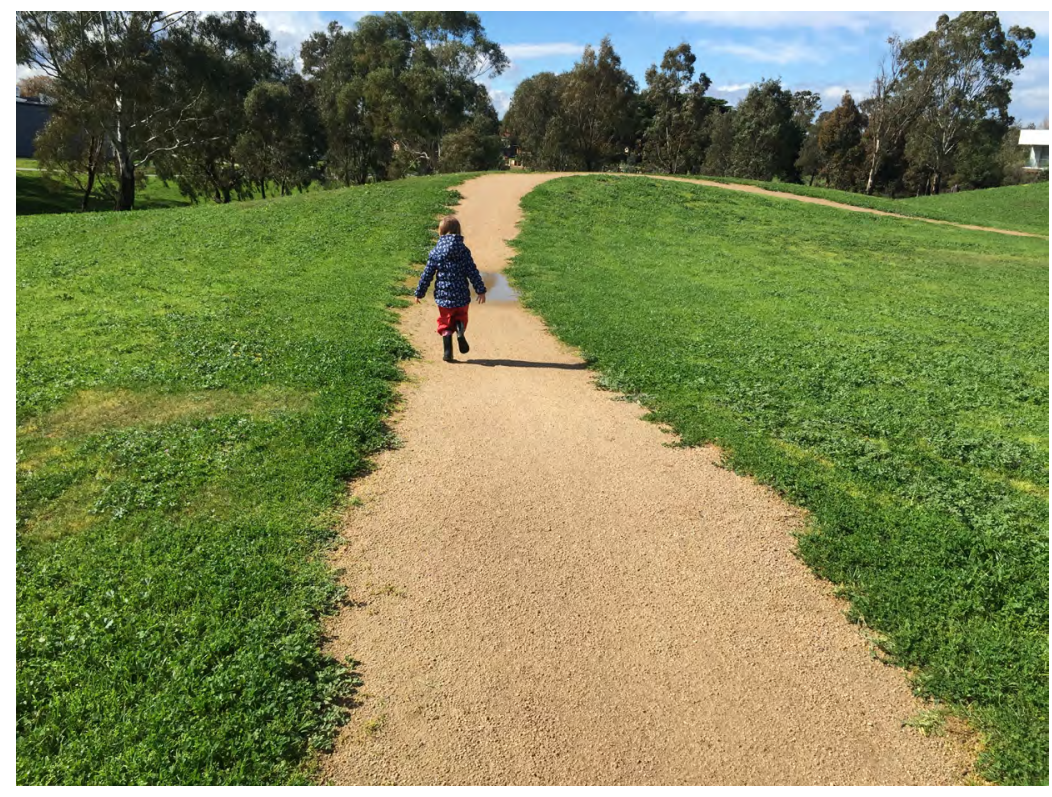

Figure 2. Unceded Wurundjeri country.

Each group is committed to place-based learning, with Arbutus Place spending extended periods of time with the nearby Haro Woods and Koala Group forming similar place relations with Cruickshank Park via their Out and About program. Brought together through the Common Worlds collective of interdisciplinary researchers (www. commonworlds.net), the children and educators of Koala Group and Arbutus Place connected each week via FaceTime over several months in 2016-17, sharing stories and questions from our Canadian and Australian contact zones. During our weekly FaceTime sessions, we invited children to generate and share small stories with each other about who or what they saw, heard, smelled, and felt. To help each other understand more about the places where they live, the children from Arbutus Place shared stories about what happened when they walked in nearby Haro Woods, and the children from the Koala Group shared stories from their Out and About walks in Cruickshank 
Park. We noticed that FaceTiming with the children prompted them to articulate their embodied and emplaced learnings and to reflect on and communicate their significant local place relations. Sharing our respective places in the FaceTiming sessions also pushed educators' and children's attunement to these places as contested settler colonial contact zones.

In recognizing the places where we live and work as settler colonial contact zones, we also work with Hamm's (2018) reconceptualization of place as a pedagogical contact zone, where human and more-than-human entanglements generate learning with and from each other. Koala Group learns with and from Cruickshank Park, on the edge of the Western Victorian basalt plains, while Arbutus Place learns with and from Haro Woods, a second-growth urban forest. Cruickshank Park was once a flourishing grassland and mangrove swamp, but since settlers quarried this place for bluestone, its repurposed creek has become a drain for heavy industry. Creek ${ }^{1}$ remains one of Victoria, Australia's most polluted, while also being host to a fluctuating population of pobblebonk frogs (Eastern Banjo

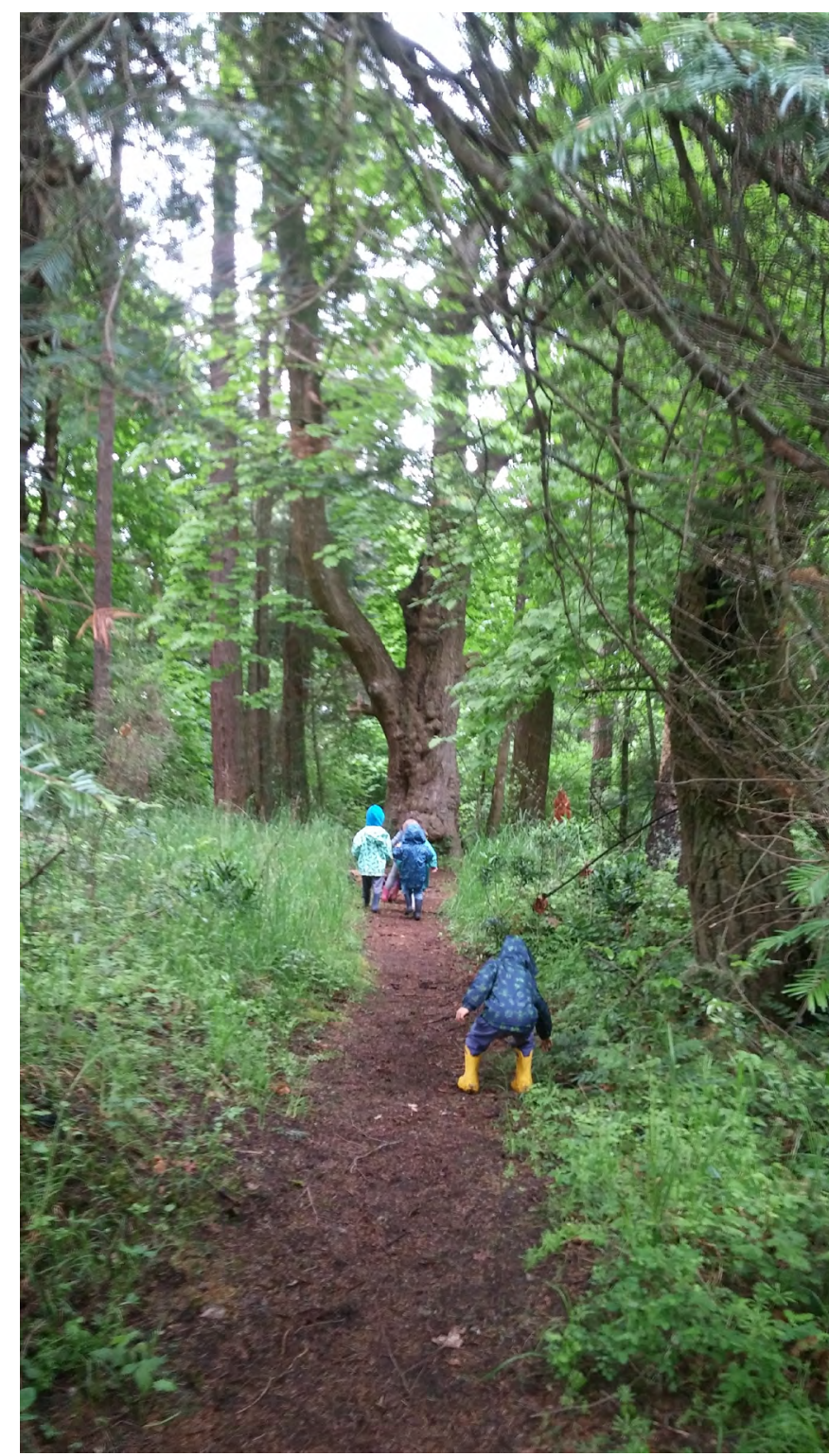

Figure 3. Unceded territory of the Lkwungen-speaking people, specifically Songhees, Esquimalt, and WSÁNEĆ peoples. or Limnodynastes dumerilii). ${ }^{2}$ Finnerty Creek is a shallow, urban-influenced drainage-to-shoreline waterway that cuts through Haro Woods, which often remains dry during summer months, only filling and flooding during heavy winter rains. Despite its industrialization, presentday Cruickshank Park provides a greenbelt for a rapidly gentrifying inner-city suburb. Along with an off-leash dog park, the park provides habitat for a range of native animals, including possums, yabbies, and many birds. Haro Woods is an assemblage of Douglas fir, hemlock, arbutus, maple, and cottonwood trees intertwined with invasive, non-native plant species such as English ivy, Himalayan blackberry, and spurge laurel. The woods are home to black-tailed deer, chestnut-backed chickadees, barred owls, banana slugs, and many other species who feed, find shelter, and migrate with(in) and through the woods. Intensified urban development and humaninduced climate change continue to cause soil and root disruption, erosion, and wildlife disturbance.

As we connect with(in) and across these pedagogical contact zones through the help of tiny iPhone screens, we work to think beyond comparing and contrasting landscapes. We are inspired by Haraway's practice of "giving and receiving, patterning, holding the unasked-for pattern in one's hands, response-ability" (2016, p. 12). We attempt to engage and ask questions that come from the messy connections that take place as we give and receive, recognizing that these contact zones draw us into situated and specific relationships with place, more-than-human others, people, and technologies. 


\section{Common worlds and string figuring}

We situate our pedagogies within the multidisciplinary conceptual framework of the Common Worlds Research Collective. This framework is concerned with reconceptualizing inclusion and place relations in early childhood by taking account of our entangled relations with all of the others in our common worlds_ "including the more than human others" (Taylor \& Giugni (2012, p. 108). A relational ontology of attending and attuning to the ethics and politics of these common worlds is central to this framework (see Rautio, 2017; Taylor, 2017) and is very much woven into the fabric of our entangled place encounters and our early childhood educator practices.

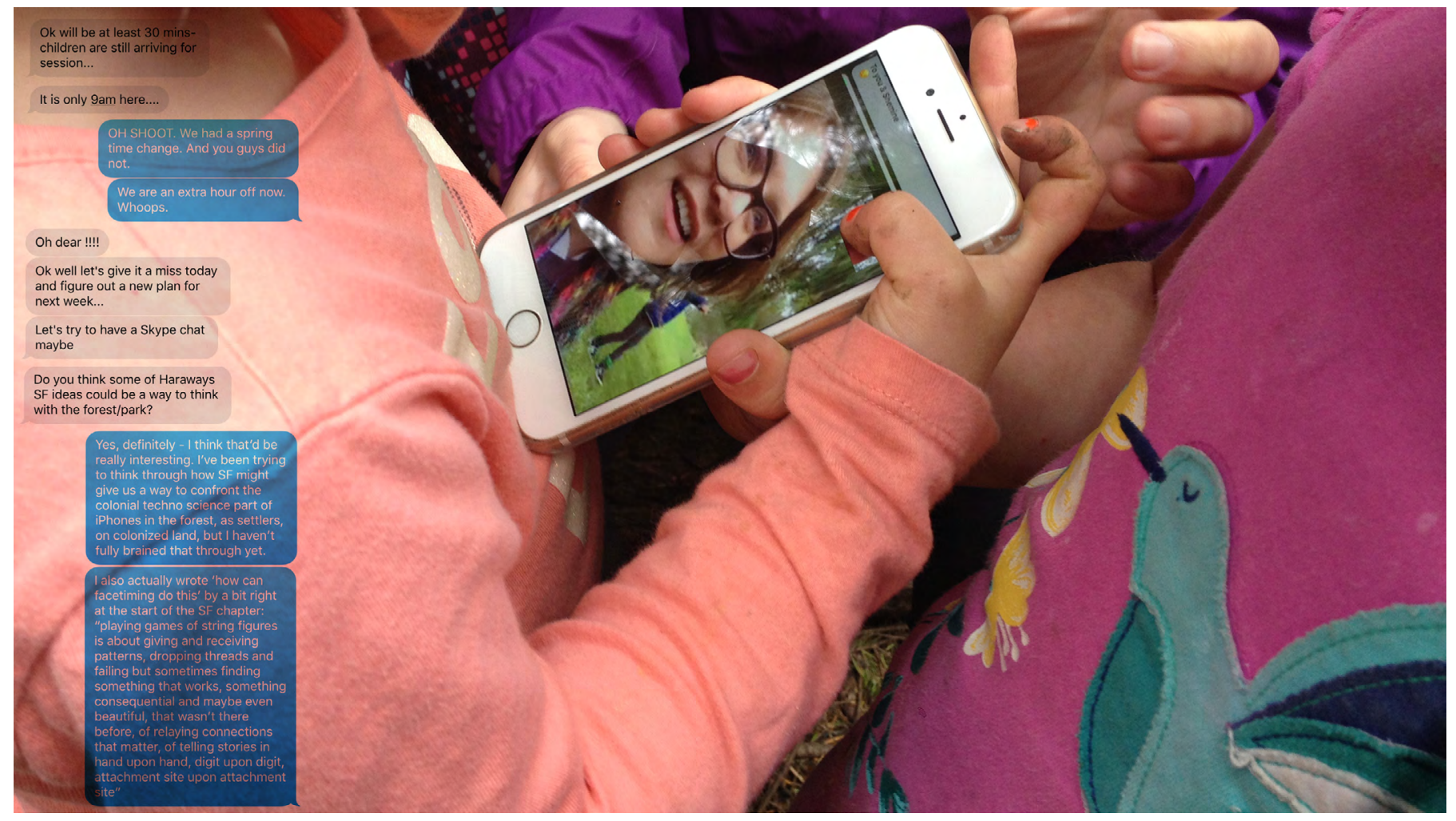

Figure 4. Attending and attuning to entangled threads.

As we weave common world pedagogies into our Australian and Canadian place encounters, we are provoked by feminist scholar Donna Haraway's (2016) writing about string figures (SF), the well-known children's game, as a method for attending and attuning to knots that continue to matter with ongoing settler colonial tensions, inequities, and inheritances. We draw on the metaphor of string figures to think in new ways about our responseabilities in and across woods and park, while cultivating practices with children. As Haraway (2016) elaborates:

Playing games of string figures is about giving and receiving patterns, dropping threads and failing but sometimes finding something that works, something consequential and maybe even beautiful, that wasn't there before, of relaying connections that matter, of telling stories hand upon hand, digit upon digit, attachment site upon attachment site, to craft conditions for finite flourishing on terra, on earth. String figures require holding still in order to receive and pass on. String figures can be played by many on all sorts of limbs, as long as the rhythm of accepting and giving is sustained. (p. 10)

Importantly, thinking with string figures helps foreground a specific ethic and method for attuning ourselves to new ways of connecting children, bodies, and places across oceans. String figuring, through FaceTime and across settler colonized contact zones, attunes us to possibilities for connecting and mattering distant worlds differently. 
We work toward connecting in ways that confuse us, that sometimes last five minutes and sometimes are sustained for a half hour, that feel challenging, that fall apart with scheduling mistakes, and that are messy and lively and slippery and imperfect-connections that matter because they actively implicate us in the process and the messy tensions of FaceTiming in settler colonial spaces. We pose questions and provocations for each other with hopes of finding something that works: Where in Haro Woods does the sound of Cruickshank's creek make us want to go? How can Arbutus Place's map help us navigate Cruickshank Park? What unfolds is a process of attending and attuning with place and with each other in new and pedagogically generative ways.

As Haraway details, "although they are among humanity's oldest games, string figures are not everywhere the same game. Like all offspring of colonizing and imperial histories, I-wehave to relearn how to conjugate worlds with partial connections and not universals and particulars" (Haraway, 2016, p. 13). Through FaceTiming across settler colonial contact zones, our string figuring threads partial connections among iPhones, colonized woods, urban parks, material exchanges, and histories of settlers sharing places that are not ours to share. Our string figures are neither complete nor innocent. For now, we grapple with how string figures and knotting might expand, complexify, or disrupt the possibilities for assumed belongings and new attachments within early childhood education pedagogies.

\section{Presencing transit (in)tensions}

On small screens we see Bunjil and Waa flying atop outstretched arms. We meet them digitally a few times as they regularly accompany Koala Group with Cruickshank Park, becoming important in the ritual of Out and About with Wurundjeri Country. With a desire to share connections with place, a second set of Bunjil and Waa puppets are packed in a suitcase and travel from Melbourne through California and

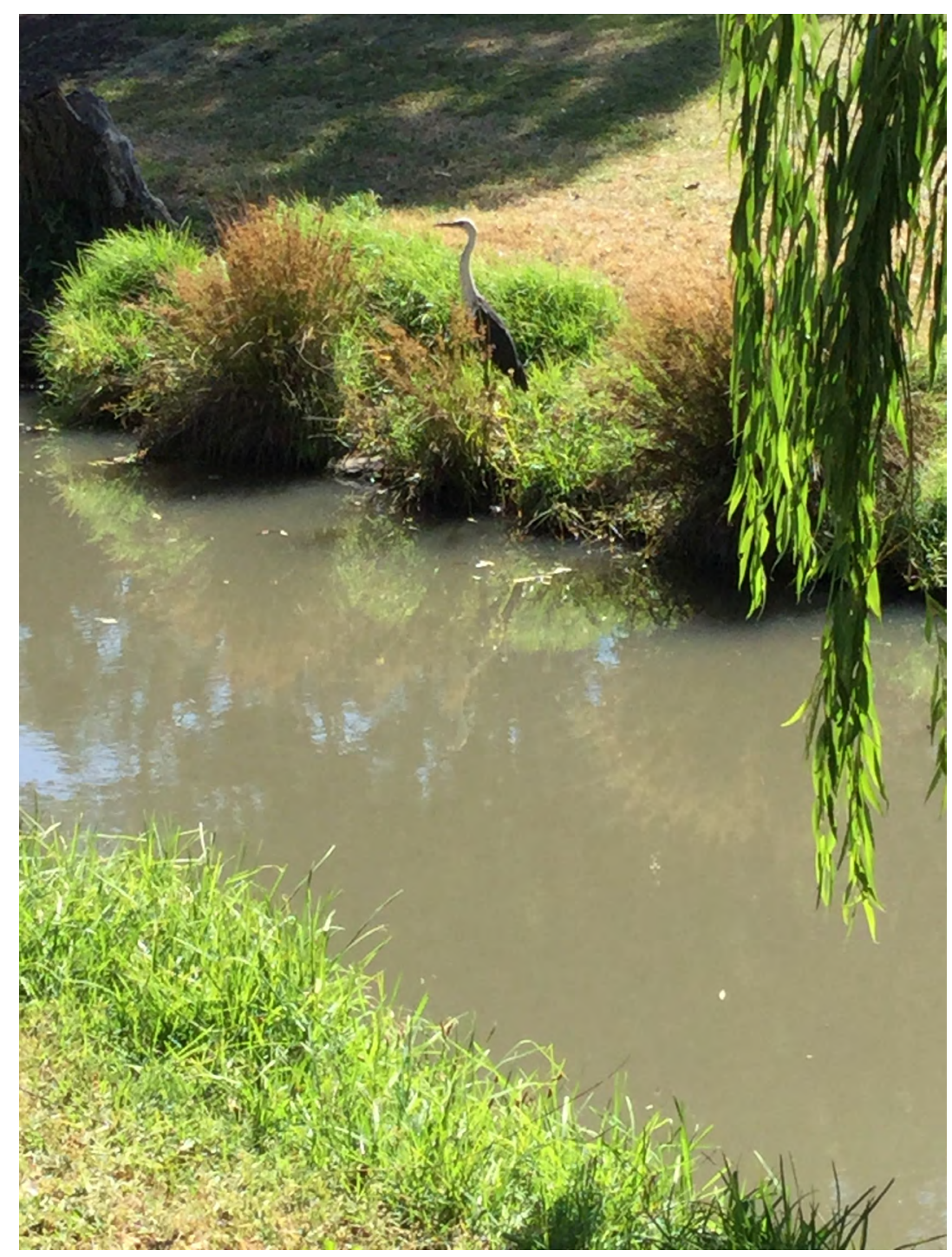

Figure 5. Where in Haro Woods does the sound of Creek make us want to go?

Texas before landing in Arbutus Place hands in Victoria, Canada. They do not arrive alone. They travel with a Welcome to Country (2016) storybook and a story about Waa written by the children of Koala Group. Upon arrival, puppets fly on Arbutus Place hands, while children struggle with pronunciations and skip to English sections of the books. What is it to have Bunjil and Waa on the unceded territories of Lkwungen-speaking peoples while also attending to Bunjil and Waa with Wurundjeri country? What is required for Arbutus Place to "properly" (or "ethically"?) receive Bunjil and Waa? What is required for the Koala Group to give them? (Arbutus Place field notes, May 2017) 
For Wurundjeri people, Bunjil is a wedgetail eagle and creator spirit while Waa is a crow and keeper of waterways. For Koala Group children and educators, they are ethically-sourced puppets that give material form to these Wurundjeri spirit animals and have been approved by local Elders for use in services like Clare Court. The children of Koala Group had introduced Bunjil and Waa to those at Arbutus Place during a few FaceTime encounters, but when our research partners in Australia outlined a plan to visit Canada it was decided a set of identical puppets would be sent to Arbutus Place.

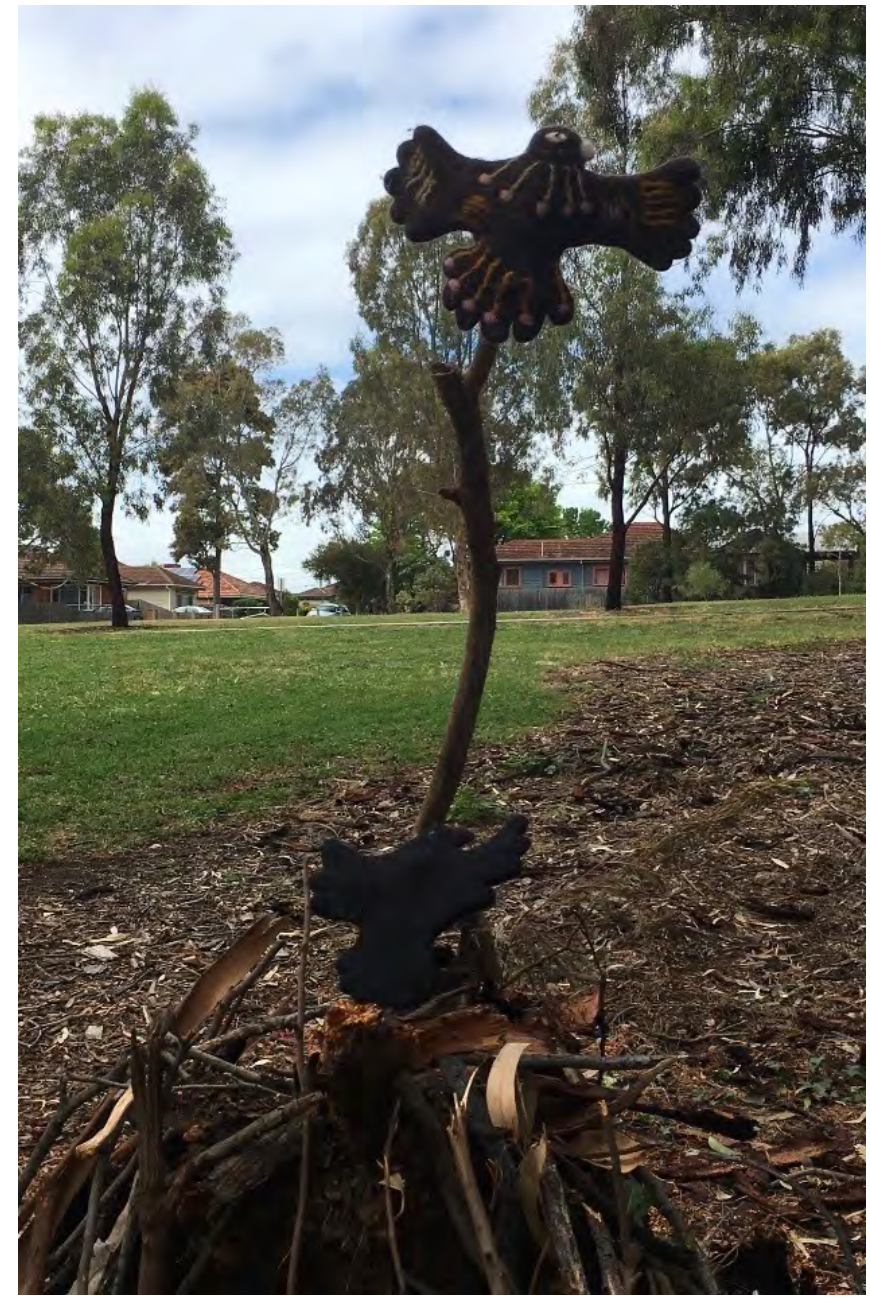

Figure 6. Bunjil and Waa out and about with Wurundjeri country.

While digital technologies were the starting point for weaving our storytelling knots, or string figures, across contact zones, these threads were pulled more tightly by the material presence of Bunjil and Waa in Victoria, Canada. Presencing transit (in)tensions feels like a good way to tell this part of the story. Even though we (the Arbutus Place educators and children) had already come to know Bunjil and Waa through FaceTime engagements, as they travelled, or transited, from the hands of Koala Group to our hands, their material presence created new tensions. It unsettled us and our pedagogy, provoking us to question sedimented notions of who and what belongs in our settler colonized places.

In writing this article, we play with the word "intension" to describe our tightening entanglements with the presencing of Bunjil and Waa. In our deliberately bracketed word play, (in)tension signifies the intensity or intensification of our feelings that were affected by Bunjil and Waa's material transition from Australia to Canada. In its official linguistic definition, intension means the internal characteristics of a term or concept that constitute its meaning (Intension, 2019). For example, the intension of the term creek means the internal characteristics of "creekness" that the word brings to mind. Of course, we are not the first to deliberately play with the word (in)tension (see, for instance, Springgay \& Truman, 2017). Cohen's blogging on the prefix in- has influenced our thinking. He describes the way in- "functions simultaneously as negative prefix and inclusive preposition, surfacing entanglement even at moments of abjection" (Cohen, 2014, para. 2). In the same way Cohen plays with the words inhuman nature to map "the activity of the things, objects, forces, elements and relations that enable, sustain and operate indifferently to the category" (para. 2), we play with the word intension to help us convey the full range of internal characteristics of "the things, objects, forces, elements and relations" that constituted our FaceTime inquiry. Lastly, we invoke the word tension to describe the pulling force we feel as Bunjil's and Waa's threads of belonging are stretched, to describe how we are affected when these Aboriginal Australian figurative bodies transit from Wurundjeri country in Australia to Songhees, Esquimalt, and WSÁNEĆ territory in Canada. Written this way, (in)tension represents not only the internal intensity of tension-ness but also our own uncomfortable entanglement in their material transition. Presencing transit (in)tensions with Bunjil and Waa unsettles us and our pedagogies, deliberately so, as they bring stories which hold us differently accountable in our 
different settler colonial contact zones. Bunjil and Waa's disconcerting presence in Canada leaves us wondering how we might generate connections that matter as they continue to complexify our pedagogical relationships as settlers, within and across our different colonized places.

The impetus to send the Bunjil and Waa puppets from Australia to Canada was threaded into the release of a new Early Years Learning Framework (Victoria Department of Education and Training, 2016) in Victoria, Australia, which calls on educators to embed practices that promote wider community understanding and appreciation of the value of Aboriginal perspectives. By sending the puppets to Canada as figurative Aboriginal Australian ambassadors, we set out not only to promote an understanding of Aboriginal Australian perspectives beyond Australian shores, but also to create a new transcontinental contact zone, with a whole new set of political tensions and knots and mutually transformative possibilities. We stay with these political knots and transformative possibilities.

In Canada, the Truth and Reconciliation

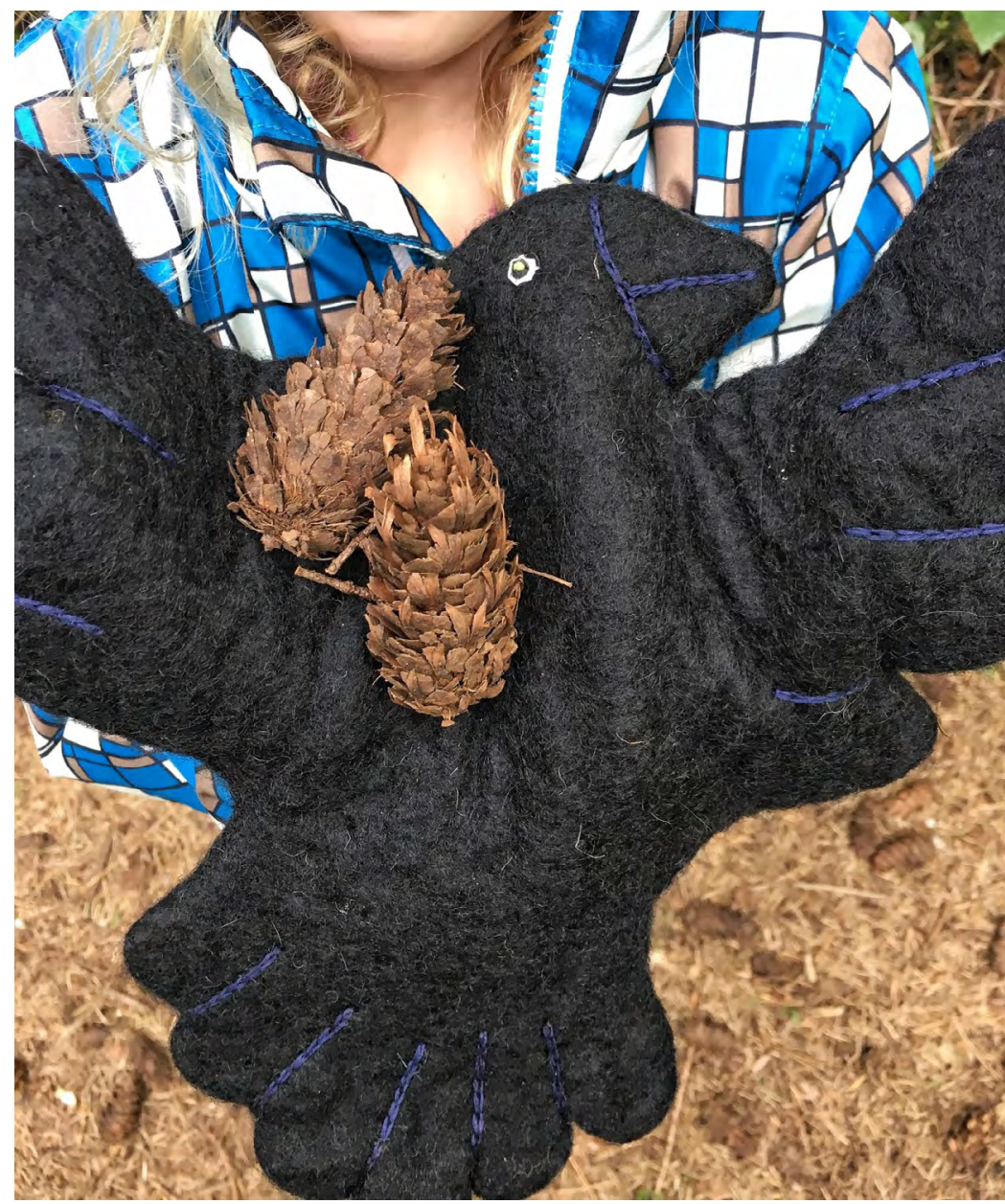

Figure 7. Pulling threads tightly with Bunjil and Waa on the unceded territory of the Lkwungen-speaking peoples. Commission's (2015) calls to action oblige educators to disseminate knowledge, educate, and work to redress injustices, a history of racism, and the impacts of colonization. Our FaceTime inquiry pedagogies were guided by the previous British Columbia Early Learning Framework (BCELF; Government of British Columbia, 2008) which provided minimal information about colonial histories and Indigenous knowledges. Since then, a revised version of the BCELF came out that foregrounds both First Peoples' principles of learning and rethinking the impact of perpetuating dominant worldviews in pedagogy and practice, adding another layer of professional responsibility and complexity to this ongoing story. At Arbutus Place, Bunjil and Waa force us, as settler educators, to confront questions outside of the BCELF: To whom or to what are we accountable as we seek to unsettle dominant curriculum practices on these traditional territories?

Australian Aboriginal scholar Karen Martin encourages early childhood educators to take up the responsibility for embedding Aboriginal perspectives and practices in early childhood pedagogies through a process she describes as "coming alongside" local Aboriginal knowledges (Martin, 2008, p. viii; 2017, p. 39). We take up her call in both Australian and Canadian contexts by attempting to thread new string figures across Western and Aboriginal worldviews and walking the fine line between cultural appropriation and respectfully embedding Indigenous knowledges in our practices. In Australia, Bunjil and Waa play a key role in our efforts to respectfully foreground Aboriginal perspectives in our curriculum. They have become familiar presences in the Koala Group room and Out and About. In Canada, Bunjil and Waa's unsettling material presence has prompted us to go deeper into 
Aboriginal Australian and Indigenous Canadian relatedness protocols. Bunjil and Waa's dual presence in both our Australian and Canadian centres has added a new dimension to our FaceTiming practices of reflecting, researching, and sharing our respective place stories. We ask, in both centres: How do we, as settler educators, respectfully embed Indigenous perspectives into curriculum? The material presence of Bunjil and Waa at Arbutus Place has unexpectedly emerged as a step toward coming to terms with this responsibility and all the inherent (in)tensions involved on both unceded Lkwungen territory and Wurundjeri country. There are no preset rules to follow in this unsettling digital-material transcontinental contact zone, and we are learning to accept that the greatest learning typically emerges from the greatest discomfort (Pacini-Ketchabaw, Nxumalo, Kocher, Elliot, \& Sanchez, 2015).

Of course, refiguring Indigenous presences and restorying place is not exactly the same everywhere, or, as Haraway puts it, "string figures are not everywhere the same game" (Haraway, 2016, p. 13). We sit with different settler accountabilities and responsibilities in different lands. In October 2017, Koala educator Miriam visited Arbutus Place and wrote in the Clare Court field note book:

Fall has come late this year and the salmon are running upstream in the forests of Lkwungen territory. The conditions feel very much like what I left behind in Australia. And yet, it is crisper, the light is different. The forest is a sharp contrast to the familiar places in Cruikshank Park. On the morning I arrive, Bunjil and Waa are perched on top of a nest the Arbutus Place children have constructed. How familiar and yet unfamiliar they seem in this new place. Their presence with the Koala Group is embedded in our routines and conversations. I'm not sure how they fit in here. (Clare Court field notes, October 2017)

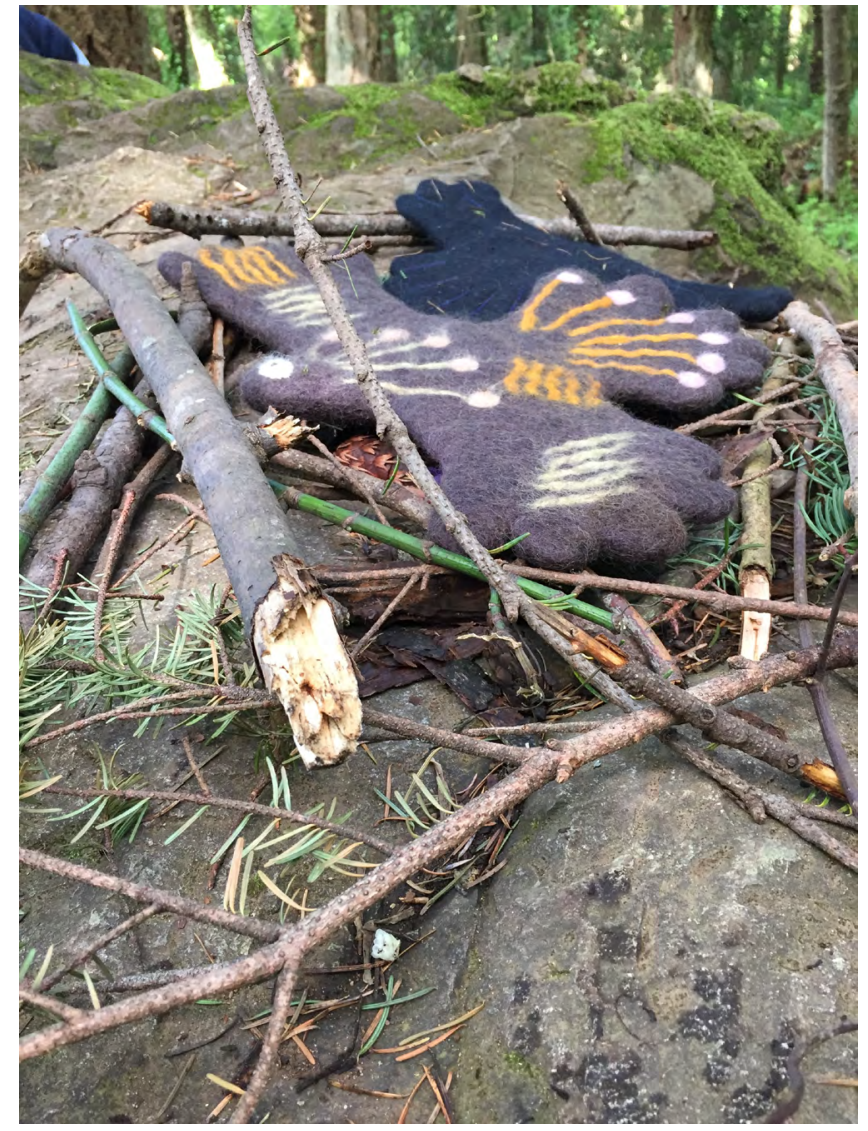

Figure 8. How familiar and yet unfamiliar Bunjil and Waa seem in this new place.
This experience has become a lesson in the uncertainty of string figuring and the significance of place affect. Bunjil and Waa stretch our thinking about how place matters in becoming accountable, generating knots and confronting settler colonialisms in our practice. In both places they provoke us to ask, what if we pay attention to the settler colonial silences and erasures in our moments with children? We draw on Fikile Nxumalo's method of refiguring presences in colonized places "as a way to creatively grapple with, interruptively respond to, as well as work through the doubts, complicated frictions, discomforts, knots and silences" (Nxumalo, 2016, p. 641). Her work provokes us to wonder how the very different emplacements of Bunjil and Waa might force us to "grapple with" in ways that refuse an impulse to smooth over our settler colonial "doubts," "frictions," and "discomforts." Judy Iseke-Barnes (2009) reminds us that in attempting to acknowledge and respect history, values, and diversity, Indigenous knowledges and stories are not static or homogenous. So, we also wonder about the unevenness of global settler colonial inheritances and the politics of taking up Indigenous knowledges across place. Bunjil and Waa stir up (in)tensions that are already present, making us reconsider methods for getting on together in settler colonial spaces. They remind us, as Nxumalo writes, to "re-animate, re-think and relate 
differently to absent presences in everyday place encounters ... and educator practices" (2016, p. 641). Can we even say Bunjil and Waa facilitated Indigenous represencing in Canada when they were never present here in the first place? Whether physically present or encountered through FaceTime, they interrupt and provoke us to reconsider, (re)story, and unsettle our settler colonial silenced practices (Nxumalo, 2016) in these territories. They call on us to confront our settler colonial contact zones and refigure our questions, asking: What happens when we bring Bunjil and Waa to both Haro Woods and Cruickshank Park-and continue to do so-because it is complex?

We wonder if thinking through a common worlding approach to recognize our entangled relations with morethan-human-others on colonized lands is also a way of coming alongside Indigenous knowledges in a culturally sensitive way (Martin, 2008, p. viii; 2017, p. 39). How do Bunjil and Waa, an eagle and a crow, stretch our possibilities for carefully attuning, thinking more about our connections to land and place, and inheriting the complexities of more-than-human common worlds? The children of the Koala Group and Arbutus Place ask:

Are Bunjil and Waa happy in Canada? Do they like Canada better than Australia? Are they coming back? Are they lonely? Do they miss where they live? What do they do? Aren't they just puppets? Should we send them back? (Clare Court and Arbutus Place field notes, February 2018)

The questions asked by the children remind us that belonging in settler colonized common worlds like Australia and Canada is never fully settled. The question of who belongs where is the central tension of settler colonial contact zones and remains messy, entangled, and troubling.

The very fact that the children were able to articulate such disconcerting questions about belonging in and out of place testifies to how our strategy of presencing transit (in)tensions has mattered. For, as Haraway writes, "It matters what we use to think other matters with; it matters what stories we tell to tell other stories with; it matters what knots knot knots, what thoughts think thoughts, what descriptions describe descriptions, what ties tie ties. It matters what stories make worlds, what worlds make stories" (Haraway, 2016, p. 35).
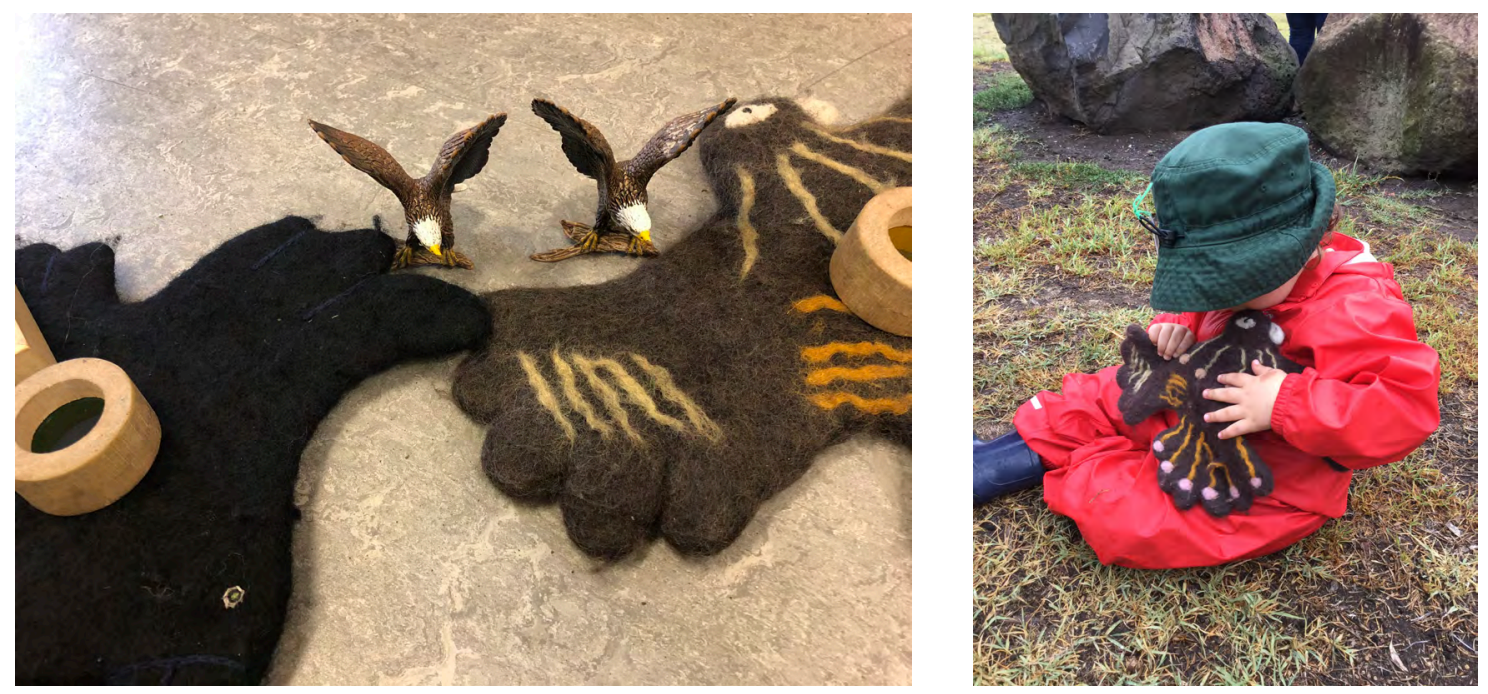

Figures 9 and 10. How might this messy work make visible our accountabilities and inheritances in places of ongoing settler colonialism?

\section{Conclusion}

Throughout this paper we have invited questions that interrupt the business-as-usual of early childhood educator practices on settler colonized lands. In it, we have raised questions that we do not really know how to answer. We 
do not know for sure what is required to care with the Indigenous stories, presences, histories, and connections that we share across oceans, and which continue to live in the settler colonized places in which we learn with young children (Pacini-Ketchabaw \& Taylor, 2015). But we do know that presencing transit (in)tensions, on both territories, with Bunjil and Waa has mattered and continues to matter. It binds us with new obligations to disrupt settler colonial relations with place and pedagogy, to refigure Indigenous presences across Euro-Western education systems, and to give and receive stories that matter for care and accountability in our common worlds.

Across 13,168 kilometres and 16 months of thinking together, we care and account for the (in)tensions entailed in the transit that we have created with Bunjil and Waa. We've carried them with our hands, our luggage, and our iPhones. We've held Bunjil and Waa with our stick nests, our concerns for their happiness and safety, and our grateful discomfort. What do these methods of giving and receiving generate? What might they ignore or obscure? How do we, along with children, answer to the complicated relationships we have created while working to think collectively with place across two different settler colonial spaces? How do we craft pedagogies and ethics that respond to the knots we've woven with children, with Bunjil and Waa, with Wurundjeri country and Lkwungen territory? These questions make visible our accountabilities and inheritances in places of ongoing settler colonialism. We will never be able to settle these questions, but we can and will continue to ask them.

\section{Acknowledgements}

We want to thank Nicole Land and Catherine Hamm for conceptualizing and bringing us all together for the FaceTiming Common Worlds inquiry. Through thought provoking and challenging us with threads of questions, they continue to think with, support, and remind us to try to tell stories, no matter how messy or uncertain, that stretch how we participate and become accountable within the common worlds.

We would also like to express our deep gratitude to Affrica Taylor, our critical reviewer, for seeing us through the editing process. Her engagement with this piece has pulled and provoked us to look deeper into the pedagogies we practice and the challenging questions we ask. Affrica's comments, questions, and edits have left us with much to think about as we continue to work with young children in these settler colonized contact zones. 


\section{References}

Cohen, J. J. (2014, June 30). Ecostitial [Blog post]. In the Middle. Retrieved from http://www.inthemedievalmiddle.com/2014/06/ecostitial. $\mathrm{html}$

Crothers, J., \& Kerr, J. (2018). Stony Creek pollution from warehouse fire "as bad as it could be" and no plan yet for clean-up. $A B C$ News, September 13. Retrieved from https://www.abc.net.au/news/2018-09-13/stony-creek-looks-dead-after-pollution-warehousefire/10238724

Hamm, C. (2018). Reimagining narratives of place: Respectfully centring Aboriginal perspectives in early childhood education. In J. M. Iorio \& W. Parnell (Eds.), Meaning making in early childhood research: Pedagogies and the personal (pp. 107-120). New York, NY: Routledge.

Haraway, D. J. (2008). When species meet. Minneapolis: University of Minnesota Press.

Haraway, D. J. (2016). Staying with the trouble: Making kin in the Chthulucene. Durham, NC: Duke University Press.

Haro Woods, Nelson, N., Yazbeck, S-L., Danis, I., Elliott, D., Wilson, J., Payjack, J., \& Pickup, A. (2018). With(in) the forest: (Re) conceptualizing pedagogies of care. Journal of Childhood Studies, 43(1), 44-59. https://doi.org/10.18357/jcs.v43i1.18264

Intension. (2019). In Collins English Dictionary. Retrieved from https://www.collinsdictionary.com/dictionary/english/intension

Iorio, J., Hamm, C., Parnell, W., \& Quintero, E. (2017). Place, matters of concern, and pedagogy: Making impactful connections with our planet. Journal of Early Childhood Teacher Education, 38(2), 121-135. https://doi.org/10.1080/10901027.2017.1306600

Iseke-Barnes, J. (2009). Unsettling fictions: Disrupting popular discourses and trickster tales in books for children. Journal of the Canadian Association for Curriculum Studies, 7(1), 24-57. Retrieved from http://citeseerx.ist.psu.edu/viewdoc/ download?doi=10.1.1.836.6488\&rep=rep1\&type=pdf

Land, N., Hamm, C., Yazbeck, S-L., Brown, M., Danis, I., Nelson, N. (2019). Facetiming common worlds: Exchanging digital place stories and crafting pedagogical contact zones. Children's Geographies. https://doi.org/10.1080/14733285.2019.1574339

Martin, K. (2008). Please knock before you enter: Aboriginal regulation of outsiders and the implications for researchers. Teneriffe, Australia: Post Pressed.

Martin, K. (Ed). (2017). Voices and visions. Aboriginal early childhood education in Australia. Mount Victoria, Australia: Pademelon Press.

Nxumalo, F. (2016). Towards "refiguring presences" as an anti-colonial orientation to research in early childhood studies. International Journal of Qualitative Studies in Education, 29(5), 640-654. https://doi.org/10.1080/09518398.2016.1139212

Nxumalo, F., \& Pacini-Ketchabaw, V. (2017). "Staying with the trouble" of child-insect-educator common worlds. Environmental Education Research, 23(10), 1414-1426. https://doi.org/10.1080/13504622.2017.1325447

Pacini-Ketchabaw, V., Nxumalo, F., Kocher, L., Elliot, E., \& Sanchez, A. (2015). Journeys: Reconceptualizing early childhood practices through pedagogical narration. Toronto, ON: University of Toronto Press.

Pacini-Ketchabaw, V., \& Taylor, A. (Eds.) (2015) Unsettling the colonialist places and spaces of early childhood education. New York \& London: Routledge.

Phillipson, R. (1992). Linguistic imperialism. Oxford, UK: Oxford University Press.

Pratt, M. (1991). Arts of the contact zone. Profession, 33-40. http://www.jstor.org/stable/25595469

Pratt, M. (1992). Under imperial eyes: Travel writing and transculturation. New York, NY: Routledge.

Rautio, P. (2017). Thinking about life and species lines with Pietari and Otto (and garlic breath). TRACE $\therefore$ Finnish Journal for HumanAnimal Studies, 3, 94-102. Retrieved from https://trace.journal.fi/article/view/63310

Springgay, S., \& Truman, S. (2017). On the need for methods beyond proceduralism: Speculative middles, (in)tensions, and responseability in research. Qualitative Inquiry, 24(3), 203-214. https://doi.org/10.1177\%2F1077800417704464 
Taylor, A. (2017). Beyond stewardship: Common world pedagogies for the Anthropocene. Environmental Education Review, 3(10), 14481461. https://doi.org/10.1080/13504622.2017.1325452

Taylor, A., \& Giugni, M. (2012). Common worlds: Reconceptualising inclusion in early childhood communities. Contemporary Issues in Early Childhood, 13(2), 108-119. https://doi.org/10.2304\%2Fciec.2012.13.2.108

Truth and Reconciliation Commission of Canada. (2015). Truth and Reconciliation Commission of Canada: Calls to action. Retrieved from http://trc.ca/assets/pdf/Calls_to_Action_English2.pdf

Victoria Department of Education and Training. (2016). Victorian early years learning and development framework. Retrieved from https://www.education.vic.gov.au/Documents/childhood/providers/edcare/veyldframework.pdf

\section{(Endnotes)}

1 In challenging linguistic imperialism (Phillipson, 1992) we purposefully seek to disrupt the language of colonialism in relation to Creek. We learn with Creek, not about it. As a result, we honour Creek as an active agent when we drop the article "the" from our language. Our language seeks to position us in the present tense, as active with Creek, rather than past passive. (Crothers \& Kerr, 2018). This catastrophic event highlights the life and death stakes of many contact zone entanglements. 